\title{
Interações bioquímicas e segurança alimentar em carnes
}

\author{
Risia Coelho Lacerda ${ }^{1}$, Fernanda Papa Spada ${ }^{2}$ e Patricia Barboza de Godoy Schiavinatto ${ }^{3}$
}

O objetivo dessa revisão consistiu na discussão das interações bioquímicas de proteínas, peptídeos, lipídios, e ácidos graxos encontrados nas carnes bovina, suína e mariscos, uma vez que esses tipos de carnes são fontes de muitos nutrientes. Durante muitas décadas, as pesquisas têm estabelecido práticas de manejo do animal e indicadores de qualidade para minimizar a incidência de carnes de qualidade inferior. Os atributos da qualidade de carnes são grandemente determinados pela taxa e extensão do declínio do $\mathrm{pH}$ no post-mortem. As interações bioquímicas do post-mortem do animal e o processo de congelamento dessa carne são responsáveis pelas mudanças da qualidade nutricional desse alimento, bem como seu tempo de armazenamento. Assim sendo, a qualidade da carne pode apresentar um impacto positivo ou negativo na segurança alimentar.

Palavras-chave: carne, interação bioquímica, nutrientes.

\section{Biochemical interacions, food safety and security in meat}

The aim of this review was to discuss the biochemical interaction of protein, peptides, lipids, and fatty acids found in meat such as beef, pork, and seafood, since they are a source of many nutrients. During several decades, exhaustive research covering various aspects of food chain has established recommended handling practices and quality indicators, in order to minimize the incidence of inferior meat quality. Meat quality attributes are largely determined by the rate and the extent of post-mortem $\mathrm{pH}$ decline. Biochemical interaction on the animal post-mortem state and in the freezing process is responsible for changing the nutrition quality of meat, as well as its shelf life. Thus, the quality of meat can have a positive or negative impact in food safety and security.

Key-words: meat, biochemical interaction, nutrients.

\footnotetext{
1 Master's degree in Science. Escola Superior de Agricultura "Luiz de Queiroz" (ESALQ), Universidade de São Paulo (USP), Departamento de Agroindústria, Alimentos e Nutrição (LAN). Correspondência: Av. Pádua Dias no 11. CEP 13418-900, Telefone: (19)34294150, Piracicaba, São Paulo, Brazil.E-mail: rc_lacerda@hotmail.com.

2 Ph.D student in Science. Escola Superior de Agricultura "Luiz de Queiroz" (ESALQ), Universidade de São Paulo (USP), Departamento de Agroindústria, Alimentos e Nutrição (LAN), Piracicaba, Sao Paulo, Brazil.

${ }^{3}$ Postdoctoral degree in Animal Nutrition. CENA - Universidade de São Paulo, Piracicaba, Sao Paulo, Brazil.
} 


\section{INTRODUCTION}

Meat and seafood have been used as food throughout the centuries. Frequently, they are the first choice as meals. In Brazil, it is not so different. Most Brazilians has one of them as their main dish daily. Therefore, Brazilians prefer beef and pork to seafood. Due to many coastal cities, Brazil offers a variety of fish and shellfish. Brazil has 5 million hectares in reservoirs, 8.5 kilometers in marine coast, and 500 thousand craft fishermen ${ }^{1]}$. According to FAO (Food and Agriculture Organization), 43.5 million people were involved worldwide in aquaculture and fishery in 2006 [2]. Beef is considered the major source of protein on a daily basis. Nowadays, beef has been more available for the population in all social classes. The reason for that is based on the decrease of its price. However, the beef consumption by the upper class is similar to the worldwide consumers, more than $50 \mathrm{~kg}$ per person/year.

Meanwhile, its average consumption is about $34 \mathrm{~kg}$ per person/year. Because of that, the industrialization of beef has expanded. Its enlargement has reached 245\% in São Paulo State during the last forty years [3]. Similar to beef, pork is often used as food for all social classes. According to Embrapa (Brazilian Agricultural Research Coorporation), its production was estimated to rise $4.5 \%$ in 2008. A methodological forecast called Swine Slaughter Systematic Survey (SSSS) was developed by Embrapa to bring important and accurate information about swine farming. Differently, seafood and freshwater fish are not considered the first choice for food.

According to WHO (World Health Organization), the consumption of these kinds of food should be about $12 \mathrm{~kg}$ per person/year, and Brazil is below it ${ }^{1]}$. Altemir Gregolin, the Brazilian Minister of Aquaculture and Fisheries, said that the rank of the Brazilian seafood production should reach $9.0 \mathrm{~kg}$ per person/year. The Brazilian Federal Government is investing U $\$ 900$ Billion for modernizing fishing boats, infrastructure, consumption measurement, and credit line. Nowadays, Brasilia is the capital city that presents the highest fish consumption percentage. In 2007, its population consumed about $12.8 \mathrm{~kg}$ per person/year. It represents 23,000 tons of fish and seafood. Bispo et al. [4] say the Brazilian seafood production was estimated in $8 \%$ from the total amount of the worldwide fishing production. Because of its demand, food companies have developed many different ways for the consumption of meat and seafood. Beef, pork, seafood, and freshwater fish are available to be purchased fresh, canned, jerked, frozen, and in cry-o-vac packages.

Therefore, it is necessary to have appropriate care about the food so that contamination can be avoided since the slaughtering until shelf life time. Hence, food companies can find ways to minimize such problems. Bispo et al. [4] say oysters, crabs, and lobsters are pointed to be one of the most dangerous ways of food poisoning because of its tendency to storage large number of pathogenic microorganisms. In this research, the authors developed a sausage enriched with vongole (Anomalocardia brasiliana), a type of shellfish, that can be safe for consumption. The aim of this review is to discuss the biochemical interactions of nutrients in meat and seafood.

\section{REVIEW}

\section{Protein Conformation and Structures}

Protein is the major nutrient of meat and seafood. Differently from seafood, meat is also rich in animal fat, a type of lipid, which can cause health problems when its intake is excessive.

Proteins are dynamic molecules, whose role depends on interactions with other molecules. These interactions are influenced by the changes of the spatial arrangement of atoms in a protein, which is called conformation [5]. The possible conformations of a protein include any structural state that can be achieved without breaking covalent bonds. A change in conformation could occur, for example, by the rotation about single bonds. However, each protein has a specific chemical or structural function, strongly suggesting that each one has a unique threedimensional structure. The three dimensional structure of a protein is determined by its amino acid sequence, as well as the function of a protein that depends on its structure. Also, an isolate protein has a unique, or nearly unique, structure. The most important forces stabilizing the specific structure maintained by a given protein are non-covalent interactions ${ }^{[}$].

Protein function often entails an interconversion between two or more structural forms. The chemical interactions that counteract the effects and stabilize the native conformation (protein structure stability) include disulfide bonds and weak (noncovalent) interactions such as hydrogen bonds, and hydrophobic and ionic interactions. These weak 
interactions have a special and important role because it shows how polypeptide chains can fold into specific secondary and tertiary structures, and combine with other proteins to form quaternary structures ${ }^{[5]}$

According to Voet et al. [6] the protein can be presented in a planar, secondary, tertiary, and quaternary structure. In a planar conformation, each peptide bond has some double-bond characters, due to resonance, and cannot be rotated. The secondary structure refers to local conformations of some parts of the polypeptide. The focus of this structure is on common regular folding patterns of the polypeptide backbone. The most prominent conformations are ahelix and $B$. The a-helix structure presents the polypeptide backbone in a tight wound around an imaginary axis draw longitudinally through the middle of the helix, and the $\mathrm{R}$ groups of the amino acids protrude outward from the helical backbone. Therefore, the amino acids sequence affects the a-helix stability. The $B$ conformation has a backbone of the polypeptide chain extended into a zigzag, rather than a helical structure. Tertiary structure has a complete three-dimensional structure and regions of a polypeptide chain can fold stably and independently, being called domains. Quaternary structure refers to the interaction between the subunits of multi-subunits proteins or large protein assemblies.

\section{Lipids}

Lipids are water-insoluble cellular components that can be extracted by non-polar solvents. Some lipids work as structural components of membranes and other storage forms of fuel. Fatty acids, which provide the hydrocarbon components of many lipids, usually have an even number of carbon atoms (usually 12 to 24) and may be saturated or unsaturated; unsaturated fatty acids have double bonds in the cis configuration. In most unsaturated fatty acids, one double bond is between carbon 9 and 10 . Triacylglicerols contain three fatty acid molecules esterified to three hydroxyl groups of glycerol, and simple tryacylglicerols contain only one type of fatty acid mixed with two or three types of tryacylglicerols. Triacylglycerols are the primary storage in fats and are presented in many types of foods including meat []].

The most abundant are the glycerophospholipids, which contain two fatty acid molecules esterified to two hydroxyl groups of glycerol. Cholesterol, a sterol, is a precursor of steroids and an important component of the plasma membranes in animal cells. Some types of lipids, like phosphatidylinositol, are hydrolyzed to yield two intracellular messengers, diacylglicerol and inositol 1, 4, 5-triphosphate. Prostaglandins, tromboxanes, leukotrienes, and steroid hormones are derived from sterols [ $[$ ].

Vitamin D, A, E, and $\mathrm{K}$ are fat soluble compounds which play important roles in the metabolism or physiology of animals. Vitamin D is precursor to a hormone that regulates calcium metabolism. Vitamin A furnishes the visual pigment of the vertebrate eye and act as a regulator of gene expression during epithelial cell growth. Vitamin E functions in the protection of membrane lipids from oxidative damage, and vitamin $\mathrm{K}$ is essential in the blood-clotting process ${ }^{[8,9]}$.

There are different sources of lipids and their classification is based on the function of their acids. The fat found on milk comes mainly from cow's milk, and goat's milk, where the majority of them are the Oleic, Palmitic, and Stearic acids. This animal fat is the only one to present a great amount of short chain fatty acids (C4 to C12), and a large amount of Butyric acid, and Cholesterol [6,7]. The Palmitic, Myristic acids are esterified in 1-sn and 2-sn positions, while the short chain milk fat is esterified in 3-sn position. Differently, the pig's fat such Palmitic acid, Stearic acid, and Linoleic acid are esterified in the central position, and in 1 -sn and 3-sn, respectively. On the other hand, the oleic acid is esterified in 1-sn and 3-sn position. Fish oil has a great amount of polyunsaturated long chain fatty acids with 20 to 24 carbon atoms. It has up to 6 double bonds and are rich in vitamin A and D, 3., EPA (Eicosapentaenoic acid), and DHA (Docosahexaenoic acid). These fatty acids are mostly esterified in position 2-sn [10].

\section{Lipid deterioration}

Lipids are very susceptible to oxidation because their chemical structures are made of saturated, unsaturated, polyunsaturated fatty acids or a mix of them. They can be oxidized by oxygen, temperature, and light exposure. Despite that, the more insaturation the chain presents the easier it is for the deterioration to happen. Because of the insaturation, fish oil is less resistant to oxidation when compared to other animal or vegetable oils. Therefore, this process leads to deterioration, which results in chemical substances called peroxides. Peroxides alter the flavor, the aspect, and the quality of the oil $[10,7]$. 


\section{Amino acids}

Protein is essential for making tissue, gene synthesis, and plasma. The digestibility of protein starts in the stomach by pepsin, followed by trypsin, chymotrypsin, enzymes responsible for degrading food protein into peptides, and peptides into amino acids. Amino acids are storaged in the liver and are released into the bloodstream when its concentration is depleted. This mechanism is called Buffering action [11]. Seafood and meat present all the essential amino acids. Therefore, seafood has a high grade in Lysine, which is the starter of the digestive process, and its digestibility is about 95\% higher than meat. Also, the amino acid content on selected portions in the carcasses of these animals show marked contrasts when compared with some of the common vegetable and cereal proteins that are in use.

The essential amino acids are Histidine, Isoleucin, Leucine, Lysine, Methionine + Cystine, Phenilanine + Tyrosine, Threonine, Tryptophan, Valine which are not manufactured by the body. Thus, all of them must be incorporated on a daily diet basis because of their important role in the human body [12]. Cyclooxygenase 1 and 2 (COX) are enzymes responsible for synthesizing prostaglandins, which are potent bioactive lipid messengers derived from arachidonic acid. Valine, isoleucine, leucine, histidine, phenylalanine, and tyrosine are formed by elements of COX 1 and 2 [13].

\section{Biochemical interaction}

\section{Enzymatic action in post-mortem foods}

The vital functions of the muscular systems cease to function at the time of death of the animal. The series of biochemical and structural events, which occur after the sacrifice, is called "conversion of muscle to meat". Biochemical and structural changes occur simultaneously and are dependent on the treatments of ante-mortem, on the slaughtering process, and on the techniques for meat storage. Glycogen is basically glucose units linked together into small hard granules stored in sarcoplasm to provide readily-available fuel that can be rapidly metabolize. It is distributed in all tissues; therefore, we have to consider it in the liver and striated muscle, where its metabolism assumes greater significance in the transformation of muscle into meat. The amount of glycogen is relevant in the study of post-mortem changes because its concentration on the muscle, moments before slaughtering, determine the formation of lactic acid, causing the $\mathrm{pH}$ to drop ${ }^{[14]}$.

Many sequential biochemical reactions that start with the activation of cellular ATPase are responsible for the physical changes which take place when muscle is converted to meat. The stiff and inextensible state - rigor mortis - which arises from a depletion of ATP, is due to the contraction of the muscle myofibrils [15]. The post-mortem changes occur because many of the native enzymes of the muscle retain most of their catalytic activity, for at least a short time after death. On the cessation of respiration in animals, glucose and oxygen are no longer supplied to resting muscle. At low blood glucose levels, glycogen is mobilized, as the alternative metabolizable energy [16].

Glycolysis is the metabolic pathway that converts muscle glycogen or glucose in pyruvic acid or lactic acid. This process is a rapid means of obtaining ATP (adenosine triphosphate) under anaerobic conditions since no oxygen is consumed. These reactions occur in the sarcoplasm, and the enzymes responsible for catalyzing each reaction are the soluble sarcoplasmic proteins. Glycolysis produces a net yield of 3 moles of ATP and four hydrogen ions per molecule of glucose-1-phosphate from glycogen [17].

Glycogen is converted to glucose-1phosphate and subsequently to piruvate. During post-mortem glycolysis of meat, changes in the concentrations of the glycolytic intermediates, such as glucose-1phosphate and glucose-6-phosphate, can be followed by the use of specific enzymatic assays for these substances in muscle extracts. Glucose-6-phosphate dehydrogenase is normally used as the detecting enzyme Due to the cessation of respiration in the muscle tissue; the postmortem glycolysis is anaerobic, so that $\mathrm{NADH}$ is no longer oxidized through the respiratory chain. Then, it accumulates as a result of the continued oxidation of D-glyceraldehyde-3-phosphate catalyzed by glyceraldehydes phosphate dehydrogenase [15].

Although this reaction is thermodynamically unfavorable, the reaction is driven by the energy released from the oxidation of the aldehyde group. Pyruvate, as the terminal products of glycolysis, cannot enter the tricarboxylic acid cycle because the accumulating NADH inhibits the key enzyme, citrate synthase [5]. However, in the presence of accumulating amounts of pyruvate, $\mathrm{NADH}$, is deoxidized by lactic acid dehydrogenase in the coupled reduction of pyruvate to lactate. Thus, glycolysis proceeds through 
the recycling of NAD. Suffice to say that lactate continues to accumulate until the glycogen supply is exhausted, as small amounts of ATP are resynthesized during glycolysis ${ }^{[18]}$.

The low $\mathrm{pH}$ value for meat, around 5.5 for meat, results from the accumulation of lactate. Any depletion of muscular glycogen reserves before death due to unrestrained struggling, as in the case of fish and incorrect handling of cattle, results in higher $\mathrm{pH}$ values [19]. Hence, meats are more susceptible to microbiological degradation [20]. Also, the stress condition, which causes lower glycogen and ATP levels, may also cause a more rapid onset of both glycolysis and rigor mortis while the carcass is still "hot" [16]. Such meats possess a lower water-holding capacity and produce excessive exudation, known as drip. It is known for the live and immediate postmortem muscle that mobilization of glycogen and the utilization of ATP are both initiated by increased concentrations of cytoplasmatic $\mathrm{Ca}+2$ ion. In the resting live muscle, the concentration of $\mathrm{Ca}+2$ in the cytosol is maintained at a very low level by a complex Ca storage and ATP-dependent pumping system in the sarcoplasmatic reticulum ${ }^{[18]}$.

Overall, the increased rates of glycolysis, caused by physical treatment of muscle, re attributed to the initial activation of phosphorylase kinase by the release of $\mathrm{CA}+2$ ions from the sarcoplasmatic reticulum [15]. Such biochemical activity of post-mortem changes in muscle fibers dependent largely on the variable release of $\mathrm{Ca}+2$ ions. It also offers a probable explanation for the different rates of glycolysis and rigor mortis observed between species, between animals, between muscles of the same animal, and even between fibers in the same muscle. Thus, individual muscle fibers differ in glycogen, ATP and Ca+2 levels, and are likely to undergo glycolysis at different rates and enter rigor mortis at different post-mortem times [14].

\section{Enzymatic action in the freezing process}

Protein degrades actomyosin during freezing process slowly, so that its hydration capacity is inhibited. On the other hand, the enzymes have their function decreased because they work in a optimum $\mathrm{pH}$ and temperature. Lipids, also present alteration in its enzymes as well as in their physicochemical properties because of low temperature. Thus, it's a restrictive factor in their storage time and shelf life [16].

\section{Antioxidant enzymes in meat}

Few studies have investigated the effects of nutrition or dietary background on the activities of antioxidant enzymes. Diet appears to modify the level of antioxidant enzymes in the circulatory and muscle systems, although no consistent effects have been observed [21]. Because of that, natural antioxidants used as food supplement seem to play a role in terms of keeping the color. The use of natural antioxidants in meat such as vitamin $\mathrm{C}$ and $\mathrm{E}$ is a good source of maintaining the color due to their safety. Therefore, the ability of vitamin C, for example, to keep the color or improve the color stability of raw meat depends on the method of incorporation into meat. It has been reported that vitamin $\mathrm{E}$ into animal diet is an effective mean to increase the level of color of the meat post mortem without exogenous intervention [22].

\section{Food Safety and Food Security}

Meat is a source of many nutrients and functions, in which science have not described them entirely, yet. Among the meat components lipids and proteins are the major nutrients. Much is discussed about the issues related to saturated fats and their metabolic effects. In terms of proteins, animal source is the most abundant one. Recently, scientists have questioned the replacement of lipids and fat animal by vegetal source having the same or similar properties [23, 24].

Despite the importance of the nutritional effects, little is known about how this group of compounds is transformed during the process of production, maturation, digestion, absorption, and decay. In addition, it is relevant to know about the bioavailability of the components in each step of digestive system. Moreover, it is very important to ensure the access of this food to people in all social levels [25].

In Brazil, Food consumption analysis should consider the social and cultural, and environmental issues. Brazil is a country with large continental dimensions, although, it shows extreme differences in regard of social levels. This feature implies that different income strata show different values in terms of familiar expenses when considering the amount of money spent with food [23]. 
It is known that the consumption of animal protein tends to be higher according to the family income. Based on this fact, it is noticed that poultry is more consumed among families than red meat. The reason for that is likely to be related with the price. Therefore, red meat has been replaced by poultry due to health concerns, especially in the middle and upper income strata. Pork consumption is limited to various types of sausages and cold meat, which shows a pronounced difference in consumption levels between income strata. The opposite is observed with fresh pork, however, these levels and consumption has been decreasing [24].

Fish consumption occurs in a decreasing manner if it is considered per capita, as well as in the percentage of the family income. However, this is a product, whose consumption has strong regional contrasts, is classified as an expensive food when it is compared with other meat. Other factors that are often mentioned as barriers are related to the need of gutting, scaling, and precarious hygienic trading conditions. The hygienic conditions of the working environment and compliance with the official requirements are important features in the production and marketing of food in order to preserve quality and safety. Meat is a perishable product and requires the use of effective and efficient methods of preservation ${ }^{23]}$.

Microorganisms are found in meat not only in the natural microflora of the animal but also by contamination during slaughtering and/or processing. Important factors should be considered such as the quality and the microbiological hygiene of the animal before slaughtering, hygienic conditions of slaughterhouses, the exposure time of the substrate at room temperature, conditions of storage, logistics, and marketing conditions ${ }^{[16,15]}$.

An important factor to be considered is the temperature. Meat products exposed to inappropriate temperatures are susceptible to immediate changes in great extension. Much attention should be given to tropical regions, where the temperature is high and the cold chain is rarely practiced without mistakes [15].

Two studies were considered on this paper, which emphasize the issue of food security in the context of marketing of meat products in Brazil. The first research Lundgren et al. [26] assessed whether the state legislation at the marketing of meat products, whose places are highly visited by local consumers, is respected in fairs and public markets in João Pessoa city, Paraiba. Another research conducted on the northern coast of São Paulo, verified the existence of illegal fish commerce and the lack of programs for monitoring the quality of water intended to cultivate these animals to be consumed by tourists and population [27].

In free markets there is an inadequate selling of perishables, such as meat, with no refrigeration. The sanitary conditions of these fairs are in disagreement with the Good Handling Practices (GHP) in the RDC Resolution № 275/2002 of the Health Department, as well as the Ordinance № 304/96, which establishes the criteria to change the distribution and marketing activities of beef, buffalo, pork and poultry, in order to protect the health of consumers. Researchers concluded that considering the microbiological standards dictated by RDC Resolution № 12/2001, the material collected attended the microbiological standards recommended by the resolution, even though the local market presented hygienic deficit due to disagreements between the legislation and the marketing of meat products [24].

Another research, conducted on the northern coast of São Paulo found that there are only two units responsible for the purification of oysters, which implies in the market of inspected and not inspected products. Thus, it causes an unfair competition in the market. Furthermore, the meat inspection burdens the fishermen causing the price of the products to rise and enables the illegal marketing. The researcher also highlights the lack of programs for monitoring the quality of water intended to cultivate these organisms. The mussels marketing is practiced locally (Ubatuba $\mathrm{SP}$ ), throughout the year, mainly in summer, due to the presence of tourists who most consume this kind of seafood. These potential consumers know almost nothing about the production and are influenced by socio-demographic and cultural issues [27].

These are the same socio-demographic and cultural issues which influence not only the European consumers but also boost Brazil in the world rank of meat production to meet all the requirements in a very demanding market. The bovine traceability is a reality in the majority of Brazilian cattle industry, in which integrates the entire production chain to a monitoring and certification system. The concept of traceability helps to identify the occurrence of abnormalities, facilitating corrective action and preventive planning, which assures the improvement of products. This perspective should be applied throughout the supply 
chain, minimizing handling errors that may influence the quality of the raw and processed meat. The implementation of traceability in the supply chain has been seen in Brazil by refrigerators which export to the European community. One of the main issues raised by consumers regarding to meat quality is related to its texture once the expectation of eating a soft steak does not always occur. The implementation of traceability helps to monitor this item whether the age is known, and maturity of the carcass is controlled during refrigeration [25].

\section{CONSIDERATION}

This review shows that animal proteins and lipids exist in a dynamic process before and after death. The essential amino acids must be part of the daily intake so that important mechanisms of the body can work properly. The enzymatic action in post-mortem foods is inevitable because enzymes remain active until glycogen, ATP and Ca+2 levels are gone. The postmortem glycolysis, also known as anaerobic glycolysis, emulates the entire enzyme activities prior to respiratory cessation. Therefore, individual muscle fibers differ in these levels so the glycolysis process happens at different rates and enters rigor mortis at different post-mortem times.

Thus, the enzymatic activity results in degradation of the essential amino acids which alters the nutrition value of the meat. Likewise, lipids also degrade because chemical structures of fatty acids are susceptible to enzyme activity as well. Despite low temperatures, proteins and lipids are degraded in the freezing process because enzymes remain active, even though there is no optimal temperature. There is a hint here of a connection between peroxides and the alteration of flavor, aspect, and quality of the oil. Hence, protein and lipid deterioration are restrictive factors in meat storage time, in shelf life, and in body nourishment. Moreover, since meat is incorporated in different strata of Brazilian consumers, awareness and knowledge about meat conservation and marketing become relevant food issues. Thus, the quality of meat can have a positive or negative impact in food safety and security as well.

\section{REFERENCES}

[1] Food and Agriculture Organization - FAO. Roma; 2013 [acesso em 20 fev 2013]. Disponível em: http//www.ftp.fao.org./fi/CDrom/P21/root17.pdf
[2] Valdimarsson G. Fish in the Global Food Supply Chain. Journal of the Institute of Food Science and Technology [internet]. 2010 [acesso em 18 maio 2011]; 24(1). Disponível em: http//www.ifst.org

[3] Empresa Brasileira de Pesquisa Agropecuária - Embrapa. Brasilia; 2011 [acesso em 18 maio 2011]. Disponível em: http//www.embrapa.gov.br

[4] Bispo E, Santana LRR, Carvalho RDS, Andrade G, Leite CC. Aproveitamento industrial de marisco na produção de lingüiça. Food Sci Technol. 2004;24(4):664-668.

[5] Oetterer M. Proteínas do Pescado. In: Oetterer M, Regitano d'Arce MAB, Spoto M. Fundamentos de Ciência e Tecnologia de Alimentos. São Paulo: Editora Manole; 2006. p. 99-102.

[6] Voet D, Voet JG, Pratt CW, Fett Neto AG. Fundamentos de Bioquímica: A vida em nível molecular. 2.ed. Porto Alegre: Artmed Editora; 2006.

[7] Nelson D, Cox M. Lehninger Principles of Biochemistry. 3.ed. New York: Worth Publishers; 2000. p.159-190.

[8] Curi D, Pompéia C, Miyasaka CK, Procopio J. Entendo a Gordura. São Paulo: Editora Manole; 2002.

[9] Combs Jr G. The Vitamins: Fundamental Aspects in Nutrition and Health. 3rd edition. Boston: Elsevier; 2008. p. 35-50.

[10] Penteado MVC. Vitaminas: Aspectos Nutricionais, Bioquímicos, Clínicos e Analíticos. São Paulo: Editora Manole; 2003.

[11] Regitano d’Arce MAB. Química Básica dos Lipídios. In: Oetterer M, Regitano d'Arce MAB, Spoto M. Fundamentos de Ciência e Tecnologia de Alimentos. São Paulo: Editora Manole; 2006. p.113.

[12] Brosnan JT. Interorgan Amino Acid Transport and its Regulation. J Nutr. 2003;133:2068S-2072S.

[13] Dreyer HC, Strycker LA, Senesac HA, Hocker AD, Smolkowski K, Shah SN, Jewett BA. Essential amino acid supplementation in patients following total knee arthroplasty. J Clin Invest., 2013;123(11):4654-4666.

[14] Simmons D, Botting RM, Hla T. Cyclooxygenase Isozymes: The Biology of Prostaglandin Synthesis and Inhibition. Pharmacol Rev. 2004;56(3):387-437.

[15] Donaldson AE, Lamon IL. Biochemistry Changes That Occur after Death: Potential Markers for Determining PostMortem Interval. PLoS One. 2013;8(11):e82011. 
[16] Ylä-Ajos M. Glycogen debranching enzyme activity in the muscles of meat producing animals [dissertação]. Helsink, Finland: Department of Food Technology - University of Helsinki; 2006.

[17] Shen QW, Du M. Role of AMP-activated protein kinase in the glycolysis of postmortem muscle. J Sci Food Agric. 2006;85(14):2401-2406.

[18] Scheffler TL, Gerrard DE. Mechanisms controlling pork quality development: The biochemistry controlling postmortem energy metabolism. Meat Sci. 2007;77:07-16.

[19] Hudson NJ. Mitochondrial treason: a driver of $\mathrm{pH}$ decline rate in post-mortem muscle? Animal Production Science. 2012;52:1107-1110.

[20] Landgraf M, Franco BDGM. Microbiologia dos Alimentos. Ribeirão Preto: Atheneu Editora; 2005.

[21] Petron MJ, Raes K, Claeys E, Lourenço M, Fremaut D, De Smet S. Effect of grazing pastures of different botanical composition on antioxidant enzyme activities and oxidative stability of lamb meat. Meat Sci. 2007;75:737-745.

[22] Bekhit AEDA, Hopkins DL, Fahri FT, Ponnnampalam EN. Oxidative processes in muscles systems and fresh meat.sources, markers, and remedies. Comprehensive Reviews in Food Science and Food Safety. 2013;12:565-597.
[23] Maluf SR. Consumo de Alimentos no Brasil: traços gerais e ações públicas locais de segurança Alimentar [internet]. [acesso em 02 abr 2011]. Disponível em: http://www.zoonews.com.br/noticias2

[24] Spada FP. Redução dos níveis de gordura em mortadela Bologna e sua influência sensorial em provadores de diferentes idades [dissertação]. Piracicaba: Escola Superior de Agricultura "Luiz de Queiroz" da USP; 2013.

[25] Lara JAF, Soares AL, Lima PN, Ida EI, Shimokomaki M. Rastreabilidade da carne bovina: uma exigência para a segurança alimentar. Semina: Ciências Agrárias. 2003;24(1):143-148.

[26] Lundgren PU, Silva JA, Maciel JF, Fernandes TM. Perfil da qualidade higiênico-sanitária da carne bovina comercializada em feiras livres e mercados públicos de João Pessoa/PB-Brasil. Alim. Nutr. 2009;20(1):113-119.

[27] Furlan EF. Vida útil dos mexilhões Perna perna cultivados no litoral norte de São Paulo: Aferição dos parâmetros físicoquímicos e microbiológicos [dissertação]. Piracicaba: Escola Superior de Agricultura "Luiz de Queiroz" da USP; 2004. 